\title{
INFLUENCE OF HORSERADISH AMORICA RUSTICANA L. AND LOVAGE LEVISTICUM OFFICINALE L. EXTRACTS ON THE STABILITY OF RAPESEED OIL
}

\author{
Lolita Tomsone ${ }^{\#}$ and Zanda Krūma \\ Faculty of Food Technology, Latvia University of Agriculture, 2 Lielā Str., Jelgava, LV-3001, LATVIA \\ \# Corresponding author, Iolita.tomsone@ @lu.Iv
}

Communicated by Inga Ciproviča

\begin{abstract}
In this study the efficiency of horseradish Amorica rusticana leaf, and Levisticum officinale lovage leaf and stem extracts for the stabilisation of rapeseed oil during storage was evaluated. Plant extracts were added to unrefined rapeseed oil in a concentration of $1 \%$ by weight, which was chosen based on the results of previous experiments studying the possibilities of the addition of different concentrations of plant extracts for extending the shelf life of the oil. As a control a rapeseed oil sample without extracts was analysed, and for comparison butylated hydroxytoluene (BHT) in the maximum allowed concentration was added to the oil. The efficiency of the extracts in oil was tested in the dark and in the light/dark cycles (day/night regime). For all samples the peroxide value, acid value and DPPH scavenging activity were determined. The oil samples with the added plant extracts stored in the dark oxidised significantly $(\mathrm{p}<0.05)$ slower than the control sample and the sample with BHT. After 24 weeks of storage, the lowest peroxide value was in the sample with the lovage stem extract. The extracts contain compounds that could absorb light (for example chlorophyll) and in the light/dark conditions accelerate oxidation in oil. Among the analysed extracts the lovage stem extract was the most effective oil oxidation inhibitor, but horseradish leaf extract was the most effective DPPH radical scavenger.
\end{abstract}

Key words: horseradish, lovage, extract, rapeseed oil, oxidation.

\section{INTRODUCTION}

In recent years the interest in plant origin supplements has increased (Brielman et al., 2006; Naczk and Shahidi, 2006) and efforts have been dedicated to research for finding new sources of antioxidants that could work as effectively as synthetic ones (Michiels et al., 2012).

Horseradish (Armoracia rusticana L.) and lovage (Levisticum officinale L.) are perennial plants in the Brassicaceae and Umbelliferae families respectively, and are cultivated in temperate climate zones. In Europe horseradish roots and leaves traditionally have been used for the treatment of gout, kidney stones, asthma and infectious diseases. Horseradish roots are well known for their culinary value imparted by their particularly pungent flavour (Raghavan, 2000). Even before vitamin C had been discovered, horseradish was used to treat scurvy (Raghavan, 2000). Horseradish, like other plants of the Brassicaceae family, contains phenolic compounds (Govere et al., 2007), volatile sulfur compounds (Kloucek et al., 2012), and also enzymes like peroxidase (Mokdad et al., 2009) and myrosinase (Belitz et al., 2009).
Regarding lovage, all parts of the plant (seeds, leaves, stems and roots) are strongly aromatic with a characteristic earthy, celery-like flavour and smell (Szebeni-Galambosi et al., 1992). Romans used lovage as a medicinal plant to reduce fever and treat dental diseases. Europeans traditionally used it as a digestive stimulant and for the treatment of skin and gynecological problems (Raghavan, 2000).

No detailed investigations are available about biologically active compounds in horseradish and lovage, but their medical properties show that they contain active substances, which could also be used for food quality improvement. The efficiency of rosemary, oregano, and green tea extracts for lipid stabilisation have been investigated quite extensively (Bhale et al., 2007; Pawar et al., 2012). Scientists also search for new sources of plants, including medicinal plants. Experiments have been performed on asparagus ( $\mathrm{Pa}-$ war et al., 2012), black currants (Mierina et al., 2011), chrysanthemum (Pukalskas et al., 2010) and evening primroses (Niklava et al., 2001). In our previous study the efficiency of lovage and horseradish extracts in different concentrations in oil under medium temperature was tested in accelerated storage conditions (Tomsone et al., 2015). In that study 
it was shown that of the tested extracts $(0.25,0.5,1$, and $1.5 \%$ by weight), 0.25 and $0.5 \%$ added extract was low to inhibit the formation of peroxide and hydroperoxides, as well as the formation of free fatty acids. The most effective extracts were those of lovage stems ( $1 \%$ by weight), horseradish leaves (1\%) and lovage leaves (1\%), and a concentration of $1 \%$ was found to be the best concentration for the stabilisation of rapeseed oil. There was no additional positive effect of adding $1.5 \%$ extract to the oil.

The aim of this study was to evaluate the effectiveness of lovage leaf and stem and horseradish leaf extracts in improving stability of unrefined rapeseed oil by extending its shelf life under conditions typical of a household environment.

\section{MATERIALS AND METHODS}

Plant material. All samples were grown in Latvia and harvested in September 2012. Horseradish (Armoracia rusticana L.) leaves were collected at the Pūre Horticultural Research Centre collection field (latitude $57^{\circ} 03^{\prime} \mathrm{N}$; longitude $22^{\circ} 91^{\prime} \mathrm{E}$ ) and the lovage (Levisticum officinale L.) stems and leaves were grown in Jelgava, Latvia (latitude $56^{\circ} 39^{\prime} \mathrm{N}$; longitude $23^{\circ} 44^{\prime} \mathrm{E}$ ).

Herb extracts. The extraction of herbs was carried out as described by Tomsone et al. (2015). After the extraction, the ethanol solvent $(96 \% \mathrm{vol})$ was completely evaporated and samples were stored at a temperature of $+5 \pm 1{ }^{\circ} \mathrm{C}$.

Rapeseed oil with extracts. Crude canola oil produced at Iecavnieks Ltd (Latvia) was used in the experiments. Initially the oil peroxide value was not higher than 6-9 microequivalents of active oxygen in a kilogram of oil (meq $\mathrm{O}_{2} \mathrm{~kg}^{-1}$ ) and the acid value ranged from 1.27 to 1.32 milligrams of potassium hydroxide $(\mathrm{KOH})$ in a gram of oil $\left(\mathrm{mg} \mathrm{KOH} \mathrm{g}^{-1}\right)$.

The Latvia Republic Regulation of the Cabinet of Ministers No. 461 (2014) states that in unrefined cold pressed rapeseed oil the peroxide value may not exceed 15 meq $\mathrm{O}_{2} \mathrm{~kg}^{-1}$, and acid value $-4 \mathrm{mg} \mathrm{KOH} \mathrm{g}^{-1}$ oil (Anonymous, 2014).

The concentration of added lovage leaf and stem extracts and horseradish leaf extract to the oil was $1 \%$. As a control, crude rapeseed oil with no additives (control sample) was analysed. The efficiency of natural antioxidants was compared with the oil sample containing $100 \mathrm{mg} \mathrm{kg}^{-1}(0.01 \%)$ of butylated hydroxytoluene (BHT), which is the allowed synthetic antioxidant for oils (EU regulation EKR 1333, 2008).

Crude rapeseed oil with added extract was placed in a conical glass flask sealed with a cork and was stirred with a magnetic stirrer $(4.0 \times$ magnets $0.5 \mathrm{~cm})$ for $30 \mathrm{~min}$ in the dark at room temperature $\left(20 \pm 1{ }^{\circ} \mathrm{C}\right)$. Twenty-one conical flasks were prepared with each type of extract. Prepared oil samples were stored in glass bottles $(50 \mathrm{~mL})$ with HDPE corks (diameter $2.4 \mathrm{~cm}$, material thickness $2 \mathrm{~mm}$ ) and kept for 24 weeks at a temperature of $22 \pm 2{ }^{\circ} \mathrm{C}$ in the dark and light/dark conditions. The experiments were performed from February 17 (light hours 9 h 41 min) till August 4 (light hours $16 \mathrm{~h} 01 \mathrm{~min}$ ). In each step of the experiment three new bottles of oil for each extract type were tested. Sample codes used in this study are as follows: C, control sample without extract; O_LL, sample with lovage leaf extract $1 \%$ by weight; O_LS, sample with lovage stem extract $1 \%$ by weight; O_HL, sample with horseradish leaf extract $1 \%$ by weight; O_BHT, sample with BHT $0.01 \%$.

Chemicals. 2,2-diphenyl-1-picrylhydraziyl (DPPH') was purchased from Sigma-Aldrich (Switzerland). All other chemicals used in the research were obtained from Acros Organic (USA).

Determination of peroxide value. Peroxide value represents amounts of primary reaction products of lipid oxidation, which can be measured by their ability to liberate iodine from potassium iodide. Peroxide value of rapeseed oil samples was determined by the standard method LVS EN ISO 3960:2010 (2010).

Determination of acid value. The acid value indicates the proportion of free fatty acid present in oil or fat, defined as the value of milligrams of caustic potassium required to neutralise the acid in $1 \mathrm{~g}$ of the sample. The acid value of crude rapeseed oil samples was determined by the method LVS EN ISO 660:2009 (2009).

Determination of antiradical activity of oil. The antiradical activity of oil was measured by the $\mathrm{DPPH}^{\prime}$ free radical scavenging method (Ha et al., 2012). Oil samples (0.15 $\mathrm{mL}$ ) were dissolved in $3.75 \mathrm{~mL}$ of isooctane. Then $1 \mathrm{~mL}$ of solution was mixed with $3 \mathrm{~mL}$ of a freshly prepared solution of $0.1 \mathrm{mM} \mathrm{DPPH}^{\prime}$ solution in isooctane. After storage for 30 minutes in the dark, absorption at wavelength 509 nm was estimated using a JENWAY 6300 spectrophotometer (Baroworld Scientifid Ltd., UK). The following formula (1) was used for calculating the oil antiradical activity.

$A R A, \%=\frac{A_{\text {control }}-A_{\text {sample }}}{A_{\text {control }}} \times 100$

where

$A_{\text {control }}$ - absorption of control sample (isooctane with DPPH'), $A_{\text {sample }}$ - absorption of analysed sample.

Statistical analysis. Experimental results were means of three measurements and were analysed by Microsoft Excel 2010 and SPSS 17.00. Analysis of variance (ANOVA) and the Tukey test were used to determine significant differences among the samples.

\section{RESULTS}

Based on the results of previous experiments (Tomsone et al., 2015), at $22{ }^{\circ} \mathrm{C}$ temperature, the efficiency of lovage 
leaf and stem and horseradish leaf extract in 1\% concentration in oil was tested.

Peroxide value. As shown in Figure 1A, in light/dark conditions in the control sample and in the sample with BHT, the peroxide value was lower than in oil samples with plant extracts. In the oil with lovage stem extract the peroxide value was lower. Although the oil samples reached the maximum peroxide value (permitted by Latvian legislation) within the first 10 weeks, the experiment was continued to observe the dynamics of the peroxide value during the oxidation process of the analysed samples.

Starting from the $10^{\text {th }}$ week of storage in the oil with BHT, the peroxide value was significantly $(p<0.05)$ lower than in the control sample and oil samples with plant extracts. At the end of the experiment, in oil samples with added plant extracts the peroxide value was $14-28 \%$ higher than in the oil with BHT and 9-22\% higher than in the control sample.

After four weeks, comparing oil samples stored at room temperature in the dark (Fig. 1B) significant differences were not detected between the samples analysed. But later, significant $(p<0.05)$ differences between samples were observed. After 12 weeks of storage, the highest peroxide value was observed in the control sample (22.33 meq active $\mathrm{O}_{2} \mathrm{~kg}^{-1}$ oil), while the lowest was found in the oil sample with the lovage stem extract ( 15.73 meq active $\mathrm{O}_{2} \mathrm{~kg}^{-1}$ oil).

During the entire experiment in the oil samples with lovage stem extract the peroxide value was the lowest among analysed oil samples and at the end of the experiment, in oil with the lovage stem extract, the peroxide value was significantly lower (36\%) compared to the control sample and lower $(25 \%)$ than in the oil sample with the commercial antioxidant (BHT).

During the experiment, all the samples that were stored in the dark tended to have a lower peroxide value than in samples stored in light/dark conditions. At the end of the experiment the peroxide value in samples stored in the dark was twice as low than in samples stored in the light/dark conditions.

Acid value. The formation of free fatty acids in the light/dark conditions was effectively prevented by BHT, and after 24 weeks of storage in the light the oil sample acid value was $2.86 \mathrm{mg} \mathrm{KOH} \mathrm{g}^{-1}$ oil (Fig. 2A). Starting with the $16^{\text {th }}$ week of storage till the end of the experiment, the acid value was the lowest in oil with BHT. Among oil samples

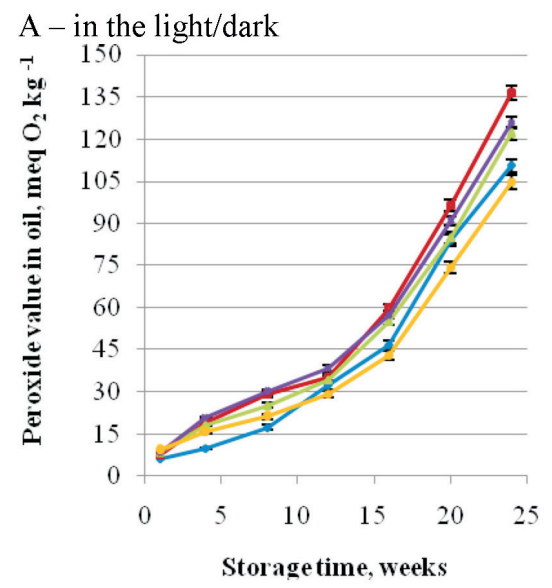

$\rightarrow \mathrm{C} \rightarrow-\mathrm{O} \_\mathrm{LL} \rightarrow \mathrm{O} \_\mathrm{LS} \rightarrow$ O_HL

$\mathrm{A}$ - in the light/dark

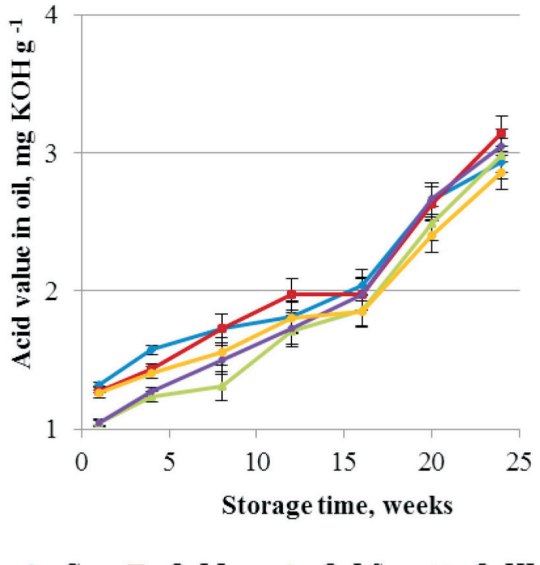

$\mathrm{B}$ - in the dark

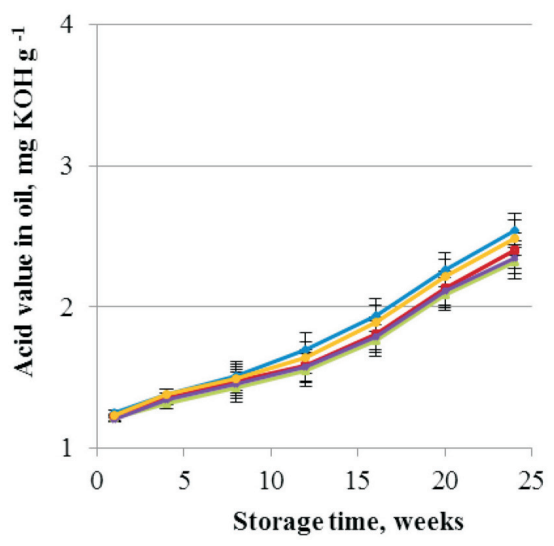

$\rightarrow \mathrm{C} \rightarrow-\mathrm{O} L L \rightarrow-\mathrm{O}$ LS $\rightarrow$ O_HL $\rightarrow$ O_BHT

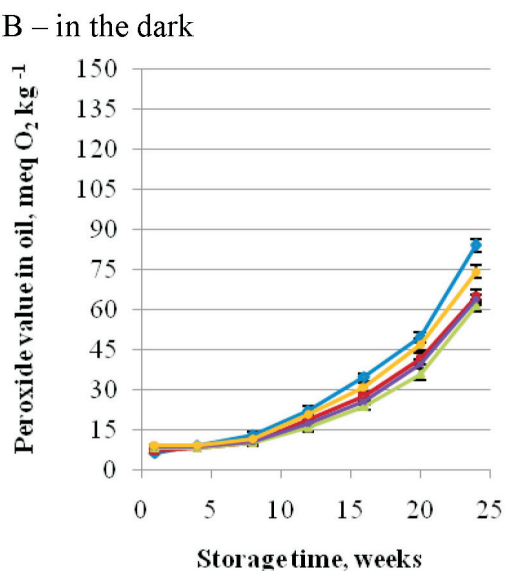

Fig. 1. Dynamics of peroxide value of rapeseed oil with horseradish and lovage extracts Sample codes used are the following: $\mathrm{C}$, control oil sample without extract; O_LL, oil sample with lovage leaf extract $1 \%$ by weight; O_LS, oil sample with lovage stem extract $1 \%$ by weight; O_HL, oil sample with horseradish leaf extract $1 \%$ by weight; O_BHT, oil sample with BHT $0.01 \%$.

Fig. 2. Dynamics of acid value of rapeseed oil with horseradish and lovage extracts. Sample codes used are the following: $\mathrm{C}$, control oil sample without extract; O_LL, oil sample with lovage leaf extract $1 \%$ by weight; O_LS, oil sample with lovage stem extract $1 \%$ by weight; O_HL, oil sample with horseradish leaf extract $1 \%$ by weight; O_BHT, oil sample with BHT $0.01 \%$. 
A - in the light/dark

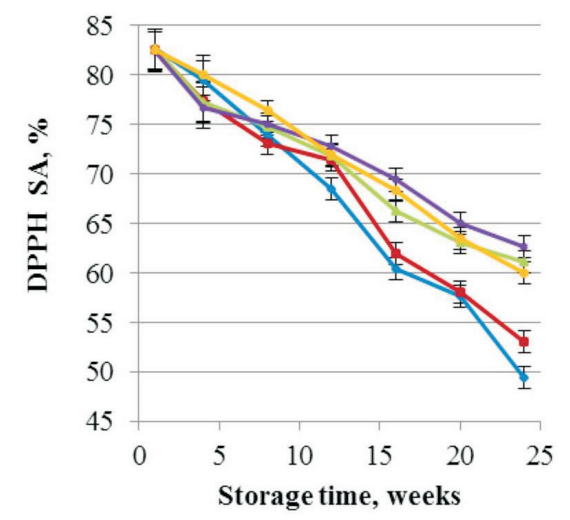

$\rightarrow-\mathrm{C} \rightarrow \mathrm{O}_{-} \mathrm{LL}$
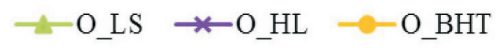

with added extracts a similar trend regarding the peroxide value was observed, and the most effective inhibitor of formation of free fatty acids after 24 weeks of storage in the light/dark was by the lovage stem extract. At the end of the experiment, in the oil samples with plant extracts the acid value was $4-9 \%$ higher than in the oil with BHT and 1-7\% higher than in the control sample.

In oil samples stored in the dark, the acid value increased more slowly than in the light/dark conditions. Among the analysed oil samples the acid value was the highest in the control sample during the entire experiment; in all the oil samples with added plant extracts the acid value was significantly $(p<0.05)$ lower. After 24 weeks, the highest acid value was in the control sample $\left(2.54 \mathrm{mg} \mathrm{KOH} \mathrm{g}^{-1}\right.$ oil), while the lowest was in the oil sample with lovage stem extract (2.32 $\mathrm{mg} \mathrm{KOH} \mathrm{g}^{-1}$ oil) (Fig. 2B). Among the oil samples with added plant extracts in the middle of the experiment differences in the acid value were the most noticeable, but after 24 weeks of storage the differences were not significant $(p<0.05)$. At the end of the experiment, in the oil samples with plant extracts the acid value was 5-9\% lower than in the oil samples with BHT and 3-7\% lower than in the control sample.

During the experiment, the acid value in all samples stored in the dark was lower than in samples stored in the light/dark conditions, and at the end of the experiment the acid value in the samples stored in the dark was 28-30\% lower than in the same samples stored in the light/dark conditions

Antioxidant activity of the added extracts in the oil. Scavenging activity (SA) of DPPH radical after 24 weeks of storage in the control oil sample in the light/dark conditions reduced from $82.83 \%$ to $49.45 \%$, while in oil with horseradish leaf extract the activity remained at $62.67 \%$, which was higher than in the oil sample with synthetic antioxidant $(60.05 \%)$ (Fig. 3A). Starting with the $8^{\text {th }}$ week of storage and till the end of the experiment, the SA of the control sample was the lowest. At the end of the experiment, in oil samples with horseradish leaf extract and lovage stem ex- tract, the SA was 4-6\% higher than in oil with BHT and $23-26 \%$ higher than in the control sample.

When stored in the dark at room temperature, the SA of oil samples decreased more slowly (Fig. 3B) than in light/dark conditions. After 24 weeks, SA was $59.69 \%$ in control samples and $67.06 \%$ oil with horseradish leaf extract. Also, when stored in the dark, starting with the $8^{\text {th }}$ week of storage and till the end of the experiment, the SA of the control sample was the lowest. At the end of the experiment, in the oil samples with horseradish leaf extract and lovage stem extract, the SA was $2-5 \%$ higher than in oil with BHT and $(8-12 \%)$ higher than in the control sample.

In unrefined rapeseed oil without added antioxidants stored for 24 weeks in the dark, the SA was higher than in the control sample stored in light/dark conditions. Similarly as for the other analysed parameters, during the entire experiment, the SA was better in all samples when the samples were stored in the dark, compared to samples stored in light/dark conditions. And at the end of the experiment. the SA in samples stored in the dark was $6-16 \%$ higher than in samples stored in the light/dark conditions.

\section{DISCUSSION}

The activity of natural antioxidants can be affected by various factors, such as by the food system to which the antioxidant is added. Therefore, in order to verify the effectiveness of the extract to stabilise lipids, oil was used as a food model. Different methods are used to evaluate the stability of lipid products, such as storage at room temperature (dark and light) and accelerated storage conditions. In the current study, changes in oil samples during storage in light/dark conditions and in the dark at room temperature were tested.

Peroxide value. The peroxide value describes peroxide and hydroperoxide concentration during the first stage of lipid oxidation. An analysis of the peroxide value is one of the most widely used methods for determining the oxidation degree of oils and fats (Gertz et al., 2000). In rapeseed oil with added plant extracts in light/dark conditions, biologically 
active compounds that can absorb light (for example chlorophyll) can have negative effects, due to properties as a sensitiser of photo-oxidation. In oil exposed to light, the extracts started to act as prooxidants and promoted the formation of peroxide in unrefined rapeseed oil, due to the presence of a singlet oxygen formation agent - for example chlorophyll. In the available literature, almost no information on the effectiveness of plant extracts to reduce oil oxidation in light conditions is found. The findings of other authors (Kim et al., 2012) show that in oil/water emulsions with added chlorophyll stored in the dark, the quantity of hydroperoxides did not change significantly, but in the light it increased due to action of chlorophyll as a prooxidant. Unrefined rapeseed oil with lovage stem extract $1 \%$ had the lowest peroxide value and also the colour was markedly more yellow and less green compared to the other samples with added extracts. This indicates that the oil sample contained less chlorophyll, and thus the oil retained greater stability when exposed to light. The results also confirmed the ability of BHT to inhibit the oxidation of crude rapeseed oil stored in light/dark conditions at room temperature. However, in dark conditions, BHT did not tend to inhibit oxidation. This suggests that the added herbal extracts were able to inhibit the oxidation of crude rapeseed oil stored in the dark more effectively compared to BHT. Similar results were obtained in medium temperature accelerated storage conditions in the dark (Tomsone et al., 2015). Pukalskas et al. (2010) also reported that BHT added to rapeseed oil and kept at $80{ }^{\circ} \mathrm{C}$ did not prevent oxidation significantly $(p<$ $0.05)$.

The oil samples with plant extracts stored in the dark reached the maximum peroxide value permitted by Latvian legislation (MKN Nr. 461 2014) during the period from 8 to 12 weeks of storage. In both control samples stored in the dark and light/dark conditions, the maximum allowed peroxide value was reached during the period from 4 to 8 weeks of storage. It indicated that the added extract retarded oxidation of the oil.

Acid value. During the storage of oil for 24 weeks in the dark and light/dark conditions, the acid value permitted in the Latvian legislation (4 $\mathrm{mg} \mathrm{KOH} \mathrm{g}^{-1}$ oil; MKN Nr. 461 2014) was not reached, suggesting that after 24 weeks of storage at room temperature there was a minimal amount of free fatty acids in crude rapeseed oil. During storage in light/dark conditions, the acid value increased more quickly compared to dark storage conditions of oil samples. In the previous experiments regarding the effectiveness of these extracts during accelerated storage conditions, the acid value increased steadily in all samples (Tomsone et al., 2015). Also, in peanut and sunflower oil samples with the added natural antioxidants stored for 40 days, the acid value increased slightly (Miguel et al., 2005).

Antioxidant activity of the added extracts in the oil. The nonpolar solvent isooctane was used in the present antiradical activity assessment. The extracts added to the oil were rich in polar compounds, therefore in these experiments it is possible that the activity of the added compounds could not be seen. Unrefined rapeseed oil already contains compounds that are able to scavenge DPPH radicals. One of the most important scavenging compounds are tocopherols, found in most cold-pressed, fruit and nut oils, which act as a natural antioxidants and synergists (Rodrigues et al., 2015). The presence of these compounds may explain the high DPPH radical SA in the control sample at the beginning of the experiment.

The SA of the oil samples with added plant extracts stored in the light at room temperature was higher compared with the control. However, the addition of plant extracts did not sufficiently prevent the formation of peroxides and the free fatty acids. This might be due to the presence of chlorophyll present in the extracts. In further experiments it is necessary to develop a method for the separation of chlorophyll before adding oil.

Compared with the control sample, the SA in unrefined rapeseed oil with horseradish leaf and lovage stem extracts was higher. A similar tendency was observed in previous experiments (Tomsone et al., 2015) on the dynamics of the $\mathrm{SA}$ in accelerated storage conditions.

Among the analysed extracts, lovage stem extract was found to be the most effective oil oxidation inhibitor, but horseradish leaf extract was the most effective DPPH radical scavanger.

\section{CONCLUSIONS}

Oil samples with the added plant extracts (1\%) stored in the dark had significantly $(p<0.05)$ lower oxidisation than in the control and in the oil with synthetic antioxidant BHT. After 24 weeks of storage, the lowest peroxide value was observed in oil with lovage stem extract. After 24 weeks, both in the light/dark and in the dark conditions stored oil with $1 \%$ horseradish leaf extract and $1 \%$ lovage stem extract showed significantly higher DPPH' scavenging activity than in oil with BHT and in the control.

Among the analysed extracts, lovage stem extract was the most effective oil oxidation inhibitor, while horseradish leaf extract was the most effective DPPH radical scavenger.

\section{ACKNOWLEDGMENTS}

The National Research Programme "Sustainable agricultural resources of high quality and healthy food production Latvian (AgroBioRes)" (2014-2017), project No. 4 "Sustainable use of local agricultural resources for development of quality and healthy food product development (FOOD)".

\section{REFERENCES}

Anonymous (2008). Regulation (EC) No 1333/2008 of the European Parliament and of the Council of 16 December 2008 on food additives. Available from: http://eur-lex.europa.eu/legal-content/EN/ALL/?uri= CELEX:32008R1333 (accessed 3 December 2017). 
Anonymous (2014). Prasības pārtikas kvalitātes shēmām, to ieviešanas, darbības, uzraudzības un kontroles kārtība [Requirements for food quality schemes, their introduction, procedure and control]. LR Ministru kabineta noteikumi Nr. 461, 12.08.2014. Available from:

https://likumi.lv/doc.php?id=268347 (accessed 3 December 2017) (in Latvian).

Belitz, H.-D., Grosch, W., Schieberle P. (2009). Food Chemistry. $4^{\text {th }}$ revised edition. Burghagen, M. (Ed.). Springer-Verlag Berlin, Heidelberg. $1070 \mathrm{pp}$.

Bhale, S. D., Xu, Z., Prinyawiwatkul, W., King, J. M., Godber, J. S. (2007). Oregano and rosemary extracts inhibit oxidation of long-chain n-3 fatty acids in menhaden oil. J. Food Sci., 72, 504-508.

Brielman, H. L., Setzer, W. N., Kaufman, P. B., Kirakosyan, A., Cseke, L. J. (2006). Phytochemicals: The chemical components of plants. In: Natural Products from Plants. Cseke, L.J., Kirakosyan, A., Kaufman, P. B., Warber, S. L., Duke, J.A., Brielmann, H.L. (eds.). CRC Press Taylor \& Francis Group, Boca Raton, FL, pp. 1-49.

Gertz, C., Klostermann, S., Kochhar, S.P. (2000). Testing and comparing oxidative stability of vegetable oils and fats at frying temperature. Eur. J. Lipid Sci. Tech., 102, 543-551.

Govere, E. M., Tonegawa, M., Bruns, M. A., Wheeler, E. F., Kephart, K. B., Voigt, J. W., Dec, J. (2007). Using minced horseradish roots and peroxides for the deodorization of swine manure: A pilot scale study. Biores. Technol., 98 (6), 1191-1198.

Ha, D. O., Yeo, J. D., Kang, S. T., Kim, M.-J., Lee, J. H. (2012) Sodium azide and metal chelator effects on 2,2-diphenyl-1-picrylhydrazyl (DPPH) radical scavenging compounds from methylene blue photosensitized lard. Eur. J Lipid Sci. Tech., 114 (7), 780-786.

Kim, T. S., Decker, E. A., Lee, J. H. (2012). Effects of chlorophyll photosensitisation on the oxidative stability in oil-in-water emulsions. Food Chem., 133 (4), 1449-1455.

Kloucek, P., Smid, J., Frankova, A., Kokoska, L., Valterova, I., Pavela, R. (2012). Fast screening method for assessment of antimicrobial activity of essential oils in vapor phase, Food Res. Int., 47 (2), 161-165.

Michiels, J. A., Kevers, C., Pincemail, J., Defraigne, J. O., Dommes, J. (2012). Extraction conditions can greatly influence antioxidant capacity assays in plant food matrices. Food Chem., 130, 986-993.
Mieriņa, I, Bondarevska, A., Jure, M. (2011). Upenuu ekstraktu ietekme uz augu eḷlas oksidatīvo stabilitāti. Mater. Sci. Appl. Chem. (Riga), 23, pp. $43-48$.

Miguel, M. G., Falcato-Simoes, M., Figueiredo, A. C., Barroso, J. M. G., Pedro, L. G., Carvalho, L. M. (2005). Evaluation of the antioxidant activity of Thymbra capitata, Thymus mastichina and Thymus camphoratus essential oils. J. Food Lipids, 12 (3), 181-197.

Mokdad, A., Mikšovski, J., Larsen, R. W. (2009). Photothermal studies of $\mathrm{CO}$ photodissociation from peroxidases from horseradish and soybean. Biochimica et Biophysica Acta (BBA). Proteins and Proteomics, 1794 (11), 1558-1565.

Naczk, M., Shahidi, F. (2006). Phenolic in cereals, fruit and vegetables: Occurrence, extraction and analysis. J. Pharmaceut. Biomed., 41, $1523-1542$.

Niklava, I., Schmidt, S., Habalova, K., Sekretar, S. (2001). Effect of evening primrose extracts on oxidative stability of sunflower and rapeseed oils. Eur. J. Lipid Sci. Tech., 103, 299-306.

Pawar, N., Arora, S., Bijoy, R. R., Wadhwa, B. K. (2012). The effects of Asparagus racemousus (shatavari) extract on oxidative stability of ghee, in relation to added natural and synthetic antiohidants. Int. J. Dairy Technol., 65 (2), 293-299.

Pukalskas, A., Venskutonis, P. R., Dijkgraaf, I., van Beek, T. A. (2010). Isolation, identification and activity of natural antioxidants from costmary (Chrysanthemum balsamita) cultivated in Lithuania. Food Chem., 122 (3), 804-811.

Raghavan U. S. (2000). A to Z spices. In: Handbook of Spices, Seasonings, and Flavorings. Raghavan, U.S. (Ed.). CRC Press, LLC, pp. 59-60.

Rodrigues, J., Miranda, I., Furquim, L., Gominho, J., Vasconcelos, M., Barradas, G., Pereira, H., Bianchi-de-Aguiar, F., Ferreira-Dias, S. (2015). Storage stability of Jatropha curcas L. Oil naturally rich in gammatocopherol. Ind. Crop. Prod., 64, 188-193.

Szebeni-Galambosi, Z., Galambosi, B., Holm, Y. (1992). Growth, yield and essential oil of lovage grown in Finland. J. Essent. Oil Res., 4, 375-380.

Tomsone L., Kruma Z. (2015). Stability of rapeseed oil with horseradish Amorica rusticana L. and lovage Levisticum officinale L. extracts under medium temperature accelerated storage conditions. Agron. Res., 13 (4), 1120-1130.

\section{MĀRRUTKU (AMORICA RUSTICANA L) LAPU, LUPSTĀJU (LEVISTICUM OFFICINALE L.) LAPU UN KĀTU EKSTRAKTU EFEKTIVITĀTE RAPŠU ELLLAS STABILIZĒŠANĀ}

Šajā pētījumā tika izvērtēta mārrutku lapu, lupstāju lapu un kātu ekstraktu efektivitāte rapšu eḷlas stabilizēšanā uzglabāšanas laikā. Augu ekstrakti tika pievienoti nerafinētai rapšu eḷai $1 \%$ (no svara) koncentrācijā, kas tika izvēlēta, balstoties uz iepriekšējo eksperimentu rezultātiem, pētot iespējas pievienot augu ekstraktus dažādās koncentrācijas, lai pagarinātu ellıas derīguma termiņu. Kā kontrole tika analizēta rapšu eḷla bez pievienota ekstrakta un salīdzināšanai vienam eḷıas paraugam tika pievienots butilhidroksitoluols (BHT) maksimāli pieḷaujamā koncentrācijā. Ekstraktu efektivitāte eḷlā tika pārbaudīta tumsas un gaismas/tumsas ciklā (diena/nakts režīmā). Visiem paraugiem noteica peroksīda skaitli, skābes skaitli un DPPH antiradikālo aktivitāti. Tumsā uzglabātie ellıas paraugi ar pievienotajiem augu ekstraktiem oksidējās būtiski $(p<0,05)$ lēnāk nekā kontroles paraugs un paraugs ar BHT. Pēc 24 uzglabāšanas nedēḷām zemākais peroksīda skaitlis bija paraugam ar lupstāju kātu ekstraktu. Gaismas/tumsas apstākḷıs pievienotie ekstrakti paātrināja oksidācijas procesu eḷıā, jo ekstrakti satur savienojumus, kas varētu absorbēt gaismu (piemēram, hlorofils). Starp analizētajiem ekstraktiem lupstāju kātu ekstrakts bija visefektīvākais eḷlas oksidācijas inhibitors, bet mārrutku lapu ekstrakts izrādījās visefektīvākais DPPH radikāḷ neitralizētājs. 